\title{
Low-enthalpy thermal waters within Khoja-Obi- Garm field (Republic of Tajikistan)
}

\author{
Anna Demonova ${ }^{1, *}$, Natalia Kharitonova ${ }^{1,2}$, Ivan Bragin $^{2}$, Georgiy Chelnokov $^{2}$, and \\ Vladimir Ivanov $^{2}$ \\ ${ }^{1}$ Lomonosov Moscow State University, Moscow, 119991, Russia \\ ${ }^{2}$ Far East Geological Institute FEB RAS, Vladivostok, 690022, Russia
}

\begin{abstract}
This paper presents data on the composition of the lowenthalpy thermal waters from the unique Khoja-Obi-Garm field located at the central part of the southern slope of the Gissar Range, in the gorge of the Khoja-Obi-Garm River, at an altitude of 1740-1960 meters. In this place, the eponymous SPA-center was built. Groundwaters from springs and boreholes of Khoja-Obi-Garm SPA has temperatures from 57 to $93{ }^{\circ} \mathrm{C}$, high $\mathrm{pH}$ (up to 8) and low TDS (less than $0.5 \mathrm{~g} / \mathrm{l}$ ). The estimated subsurface temperatures for the same thermal waters vary from $140{ }^{\circ} \mathrm{C}$ to $156{ }^{\circ} \mathrm{C}$ and $193-197{ }^{\circ} \mathrm{C}$ based on the silica and $\mathrm{K} / \mathrm{Na}$ geothermometer temperatures consequently. These waters belong to $\mathrm{Na}-\mathrm{SO}_{4}-\mathrm{HCO}_{3}$ type with high content of $\mathrm{H}_{2} \mathrm{SiO}_{3}(\sim 140 \mathrm{mg} / \mathrm{l}), \mathrm{F}$ (up to $18 \mathrm{mg} / \mathrm{l}$ ) and $\mathrm{Rn}$ (up to $814 \mathrm{~Bq} / \mathrm{l})$. Thermodynamic speciation indicated that these groundwaters are supersaturated with clay minerals and low-temperature zeolites and undersaturated with carbonate and main alumosilicate minerals.
\end{abstract}

\section{Introduction}

Currently, over 125 deposits of mineral waters with different chemical composition are found on the territory of Tajikistan [1]. The most valuable natural medical resources were established as a result of geological exploration work for the detection of mineral waters, in complex surveys of resort areas, in collection and systematization of data from long-term observations of changes of composition of mineral waters.

The main balneological indicators of the curative significance of mineral waters are: 1) temperature; 2) the presence of dissolved and free gases; 3 ) content of specific elements; 4) radioactivity. Thus these waters can be divided into eponymous groups of mineral waters.

Thermal waters are usually referred to as groundwater with a temperature of $20{ }^{\circ} \mathrm{C}$ or higher. The temperature of $20^{\circ} \mathrm{C}$ is a conventional boundary between cold (less mobile) and thermal (more mobile) waters, because at this temperature the viscosity of water, which determines its mobility, is 1 cis $\left(1 * 10^{-3} \mathrm{~Pa}^{*} \mathrm{~s}\right)$.

For the last several decades, low-enthalpy waters attracted particular attention of many scientists due to their unique chemical characteristic and active usage for geothermal and

\footnotetext{
* Corresponding author: danna1985@yandex.ru
} 
balneological purposes. In spite of numerous studies [2-6], several problems still stay unsolved till now. The most significant ones are the genesis of waters and their chemical composition evolution during upwelling; hydrogeological and tectonic settings of reservoir and depths of the water circulation; the rate of water interaction with bedrocks.

The main aim of our study is to understand the genesis of thermomineral waters at Khoja-Obi-Garm. Therewith we tried to estimate the reservoir temperatures and depth of circulation.

\section{Geological and hydrogeological settings}

The Khoja-Obi-Garm thermal water deposit is located $48 \mathrm{~km}$ northward Dushanbe, in the central part of the southern slope of Gissar ridge in the Khoja-Obi-Garm river catchment, at an altitude of 1740-1960 meters. The formation of a modern configuration of the relief was greatly influenced by the destructive activity of water, wind and especially deep erosion of rivers and streams caused by the tectonics of the area [7]. It is confined to the Gissar Ridge of the Pamir-Alai mountain system. The basic structural unit is a zone of rocks crushed under the Khoja-Obi-Garm fault of latitudinal stretch, which belongs to Alpine tectonics.

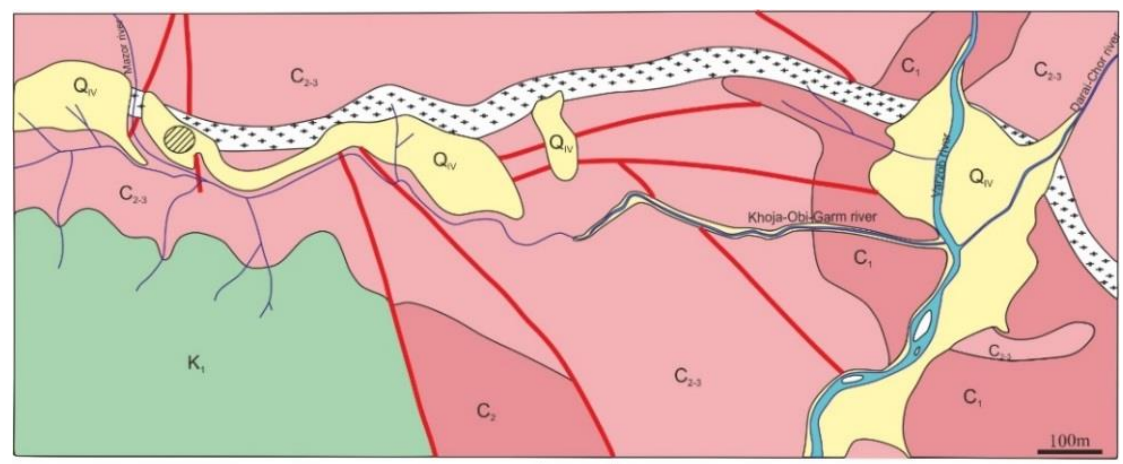

Legend:
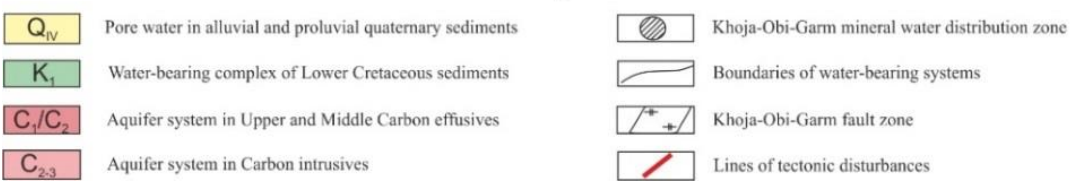

Fig. 1. Hydrogeological scheme of the Khoja-Obi-Garm-thermal waters area.

Paleozoic deposits are represented by volcanogenic complexes of Namur suite (basalts and basalt mandelstein) and Bashkirian suite (andesites, andesitic-dacite porphyrites, and tuffs with insignificant layers of marbled limestones) of the lower Carbon system [7]. Mesozoic sediments overlie the eroded surface of Palaeozoic ones. They are represented by sediments (sandstones, clays, conglomerates, etc.) of the lower group of the Cretaceous System. Quaternary deposits have a limited distribution and presented by boulders, pebbles, sand, and etc (Fig. 1).

Hydrological conditions are complex and are mainly defined by geological and structural settings of the area. Khoja-Obi-Garm waters belong to fracture thermal mineral waters confined to a strong crushing zone of granites caused by Khoja-Obi-Garm regional fault contacting with NNW disturbance [8]. 


\section{Methods}

Groundwater samples were collected during 2015-2016 from boreholes while unstable parameters (temperature, $\mathrm{pH}$, Eh, conductivity and $\mathrm{HCO}_{3}$ - values) were measured directly in the field. Samples were collected into acid-washed, high-density polyethylene sampling bottles, before sampling all waters samples were filtered through cellulose filters $(0.45 \mu \mathrm{m})$.

Major cations and anions were analyzed by ion chromatography. Trace element concentrations in groundwater samples were determined by ICP-MS analysis with analytical precision better than 5\% RSD.

Solute geothermometers based on $\mathrm{Na} / \mathrm{K}, \mathrm{K} / \mathrm{Mg}$, and the $\mathrm{SiO}_{2}$ concentrations were used to estimate the subsurface temperatures of geothermal reservoir [9-11].

\section{Results and discussion}

Following analytical data, Khoja-Obi-Garm thermal waters belong to chloride-sulfatesodium bicarbonate siliceous type of mineral waters. Hydrocarbonate, bicarbonate, and sodium dominate in almost all boreholes, whereas the contents of calcium, magnesium and potassium are low. Water mineralization is up to $0.4 \mathrm{~g} / \mathrm{l}$. The main cations and anions are shown on the triple diagram of the chemical composition (Fig. 2).

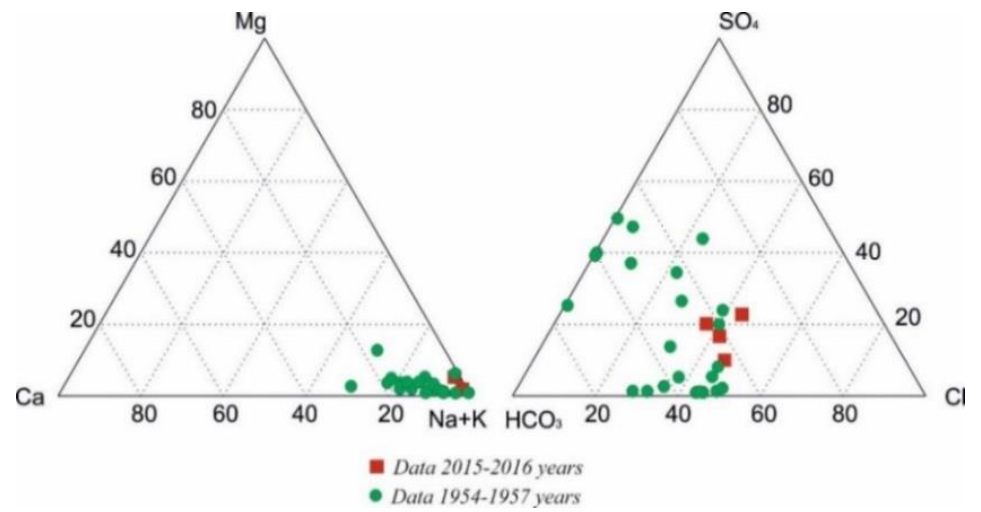

Fig. 2. Triple diagram of the chemical composition of the thermal waters of the Khoja-Obi-Garm field.

The water of the springs is characterized by a relatively high content of silica acid, varying from 78 to $139 \mathrm{mg} / \mathrm{l}$ between wells, with average value about $105 \mathrm{mg} / \mathrm{l}$. The amount of free carbon dioxide varies in the range of $2-6 \mathrm{mg} / \mathrm{l}$ and hydrogen sulfide $\left(\mathrm{H}_{2} \mathrm{~S}\right)-$ $3.54 \mathrm{mg} / \mathrm{l}$. Measured radon concentration was $814 \mathrm{~Bq} / \mathrm{l}$. A positive correlation between sodium and silica acid is observed, indicating the main water-rock interaction process plagioclase alteration. Whereas negative sodium/calcium correlation indicates thermodynamic peculiarity of water/calcite equilibrium [9].

The distribution of trace elements in thermal groundwater samples is shown in Figure 3. These therms are strongly enriched in $\mathrm{Li}, \mathrm{Rb}, \mathrm{Cs}$, and $\mathrm{Be}$.

New unique data on the microcomponent as well as REE composition of the thermal waters have been obtained (Table1). It is known that $\mathrm{pH}$ value is the main parameter, controlling REE content in water. Alkaline conditions (with $\mathrm{pH}$ values higher than 7.5) lead to a reduction in the amount of REE [12]. That is why REE concentrations in studied thermal waters are generally low and do not exceed $1 \mu \mathrm{g} / \mathrm{l}[13]$. 


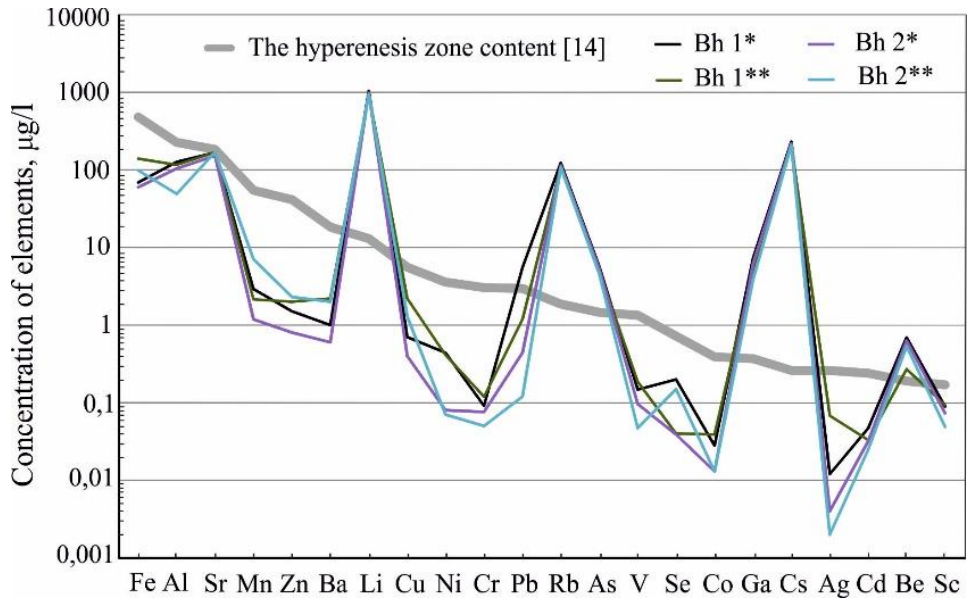

Fig. 3. The trace elements in the thermal groundwaters within the Khoja-Obi-Garm field. Data from water samples: * - collecting 2015 y., **- collecting 2016 y.

Thermodynamic calculations using cation as well as quartz geothermometers indicate that the temperature of the deep groundwater reservoir may vary in the range of 135-198 ${ }^{\circ} \mathrm{C}$. Taking into account this data, and using the geothermal gradient for Tien Shan mountain system $\sim 70{ }^{\circ} \mathrm{C} / \mathrm{km}$, we can conclude that water can be penetrated to the depth of 2-3 km during the circulation.

Table 1. The average contents of microelements ( $\mu \mathrm{g} / \mathrm{l})$ and rare-earth elements $(\mathrm{ng} / \mathrm{l})$ in thermal waters of the Khoja-Obi-Garm spa (sampling in 2015-2016).

\begin{tabular}{|c|c|c|c|c|c|c|}
\hline Elements & $\begin{array}{c}\text { Borehole } \\
\text { cluster 1 }\end{array}$ & $\begin{array}{c}\text { Borehole } \\
\text { cluster 2 }\end{array}$ & $\begin{array}{c}\text { Content in the } \\
\text { hypergenesis zone } \\
{[\mathbf{1 4}]}\end{array}$ & REEs & $\begin{array}{c}\text { Borehole } \\
\text { cluster 1 }\end{array}$ & $\begin{array}{c}\text { Borehole } \\
\text { cluster 2 }\end{array}$ \\
\hline $\mathrm{Li}$ & 990,9 & 953,3 & 13 & $\mathrm{La}$ & 85 & 90 \\
\hline $\mathrm{Be}$ & 0,481 & 0,58 & 0,19 & $\mathrm{Ce}$ & 138 & 156 \\
\hline $\mathrm{Al}$ & 121,1 & 76,5 & 226 & $\mathrm{Pr}$ & 16 & 21 \\
\hline $\mathrm{Sc}$ & 0,091 & 0,061 & 0,17 & $\mathrm{Nd}$ & 63 & 79 \\
\hline $\mathrm{V}$ & 0,167 & 0,072 & 1,34 & $\mathrm{Sm}$ & 14 & 15 \\
\hline $\mathrm{Cr}$ & 0,105 & 0,063 & 3,03 & $\mathrm{Eu}$ & 3 & 3 \\
\hline $\mathrm{Mn}$ & 2,53 & 4,11 & 54,5 & $\mathrm{Gd}$ & 14 & 16 \\
\hline $\mathrm{Fe}$ & 104,2 & 79 & 481 & $\mathrm{~Tb}$ & 2 & 2 \\
\hline $\mathrm{Co}$ & 0,034 & 0,013 & 0,39 & $\mathrm{Dy}$ & 9 & 12 \\
\hline $\mathrm{Ni}$ & 0,425 & 0,075 & 3,58 & $\mathrm{Ho}$ & 2 & 2 \\
\hline $\mathrm{Cu}$ & 1,45 & 0,85 & 5,58 & $\mathrm{Er}$ & 6 & 6 \\
\hline $\mathrm{Zn}$ & 1,75 & 1,55 & 41,4 & $\mathrm{Tm}$ & 1 & 1 \\
\hline $\mathrm{Ga}$ & 6,185 & 5,017 & 0,37 & $\mathrm{Yb}$ & 4 & 5 \\
\hline $\mathrm{As}$ & 5,31 & 4,96 & 1,46 & $\mathrm{Lu}$ & 1 & 1 \\
\hline $\mathrm{Se}$ & 0,120 & 0,094 & 0,72 & $\sum \mathrm{REE}$ & 358 & 410 \\
\hline $\mathrm{Rb}$ & 116,00 & 110,55 & 1,86 & $\sum \mathrm{LREE}$ & 319 & 365 \\
\hline $\mathrm{Sr}$ & 167,74 & 160,48 & 183 & $\sum \mathrm{HREE}$ & 39 & 45 \\
\hline $\mathrm{Ag}$ & 0,04 & 0,003 & 0,26 & $\mathrm{LREE} \%$ & 89.1 & 89.0 \\
\hline $\mathrm{Cd}$ & 0,04 & 0,029 & 0,24 & $\mathrm{Ce} / \mathrm{Ce} *$ & -0.096 & -0.103 \\
\hline $\mathrm{Cs}$ & 218,9 & 211,1 & 0,26 & $\mathrm{Eu} / \mathrm{Eu} *$ & -0.003 & 0.001 \\
\hline $\mathrm{Ba}$ & 1,6 & 1,3 & 18,3 & $\mathrm{Dy} / \mathrm{Dy} *$ & -0.117 & -0.089 \\
\hline $\mathrm{Pb}$ & 3,34 & 0,28 & 2,97 & $\mathrm{Ho} / \mathrm{Ho} *$ & 0.099 & 0.099 \\
\hline
\end{tabular}




\section{Conclusions}

Probably, the low mineralization of the thermal waters indicates that the leaching processes of igneous aluminosilicate rocks, even at such a high temperatures $\left(>100^{\circ} \mathrm{C}\right)$, are very limited and slowed down, and consequently cannot give any significant enrichment with various components. High water temperature on the surface up to $90-100{ }^{\circ} \mathrm{C}$ indicates that the formation occurs at depths of up to 2-3 kilometers and depends on the fracturing that is developed in the rocks under tectonic activity. Thermodynamic calculations and the depth of the reservoir confirm these assumptions. The conducted studies show that the temperature does not change much over more than 50 years. Interacting with water-bearing rocks at depth at high temperatures and pressure, meteoric waters are being enriched with various components.

For many balneological properties, thermal water of Khoja-Obi-Garm deposit has no analogs in the World.

The reported study was funded by RFBR according to the research project № 18-05-00445.

\section{References}

1. B.H. Razykov. Features of accommodation and economic evaluation of Tajikistan's mineral waters. (Dushanbe, Donish, 2007)

2. Y. Taran, S. Inguaggiato, G. Capasso, R. Favara, N. Varley. Geofisica Int. 41, 4 (2002)

3. A.M. Plyusnin, M.K. Chernyavskii, V.F. Posokhov. Geochem. Int. 46, 10 (2008)

4. L.V. Zamana. Dokl. Earth Sci. 372, 4 (2000)

5. I.V. Bragin, G.A. Chelnokov, O.V. Chudaev, N.A. Kharitonova, S.V. Vysotskiy. Acta Geol. Sinica, 90, 1 (2016)

6. G.A. Chelnokov, E.G. Kalitina, I.V. Bragin, N.A. Kharitonova. Rus. Jour. Pacific Geol. 8, 6 (2014)

7. R.B. Baratov. Geology and petrography of the Khoja-Obi-Garm thermal springs. (Report, Dushanbe, 1946)

8. A.A. Shapar, V.G. Tuev. The results of exploratory hydrogeological work on the site of the thermal waters of Khodja-Obi-Garm. (Report, Dushanbe, 1967)

9. A.Y. Demonova, N.A. Kharitonova, A.V.Korzun, A.I. Sardorov, G.A. Chelnokov. Moscow University Geology Bulletin, 6, 72 (2017)

10. A. Demonova, N. Kharitonova, A. Korzun, G. Chelnokov and I. Bragin (Materials of 2nd Inter. Multidiscipl. Conf. on Mineral Waters, Vila de Luso, Portugal, 2017)

11. A. Demonova, N. Kharitonova, I. Bragin, G. Chelnokov. 11th Int. Hydrogeol. Congress, National techn. un-t of Athens, 2 (2017)

12. E.R. Sholkovitz. Aquatic Geochem., 1, 1 (1995)

13. N.A. Kharitonova, E.A. Vakh, G.A. Chelnokov, O.V. Chudaev, I.A. Aleksandrov, I.V. Bragin. Russ. Jour. of Pacific Geol., 10, 2 (2016)

14. S.L. Shvartsev. Hydrogeochemistry of the hypergenesis zone. Geochemistry International, 38 (2000). 